\title{
NASA Advanced Refrigerator/Freezer Technology Development Project Overview
}

J.E. Cairelli

Lewis Research Center

Cleveland, Ohio

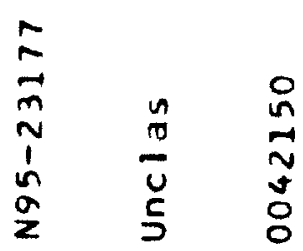

Prepared for the

8th International Cryocooler Conference sponsored by the ICC Conference Committee Vail, Colorado, June 28-30, 1994

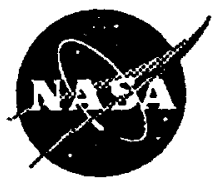

National Aeronautics and Space Administration

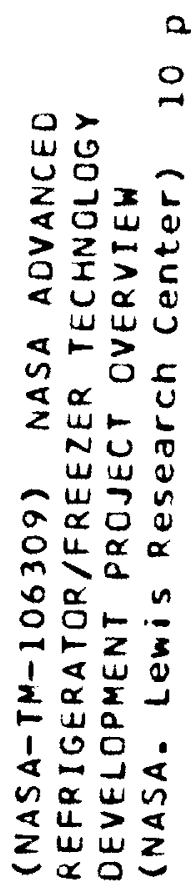




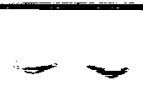




\title{
NASA ADVANCED REFRIGERATOR/FREEZER TECHNOLOGY DEVELOPMENT PROJECT OVERVIEW
}

\author{
J.E. Cairelli \\ National Aeronautics and Space Administration \\ Lewis Research Center \\ Cleveland, Ohio 44135
}

\begin{abstract}
NASA Lewis Research Center (LeRC) has recently initiated a three-year project to develop the advanced refrigerator/freezer $(R / F)$ technologies needed to support future life and biomedical sciences space experiments. Refrigerator/freezer laboratory equipment, most of which needs to be developed, is enabling to about $75 \%$ of the planned space station life and biomedical sciences experiments. These experiments will require five different classes of equipment: three storage freezers operating at $-20^{\circ} \mathrm{C},-70^{\circ} \mathrm{C}$ and $\leq 183^{\circ} \mathrm{C}$, a $-70^{\circ} \mathrm{C}$ freeze-dryer, and a cryogenic $\left(\leq 183^{\circ} \mathrm{C}\right)$ quick/snap freezer. This project is in response to a survey of cooling system technologies, performed by a team of NASA scientists and engineers. The team found that the technologies, required for future R/F systems to support life and biomedical sciences spaceflight experiments, do not exist at an adequate state of development and concluded that a program to develop the advanced R/F technologies is needed. Limitations on spaceflight system size, mass, and power consumption present a significant challenge in developing these systems. This paper presents some background and a description of the Advanced R/F Technology Development Project, project approach and schedule, general description of the R/F systems, and a review of the major R/F equipment requirements.
\end{abstract}

\section{INTRODUCTION}

To date, a small number of R/F systems have been developed for manned space applications and have been used on several Shuttle missions. The Orbiter Refrigerator/Freezer (OR/F) and Life Science Laboratory Equipment (LSLE) units have been developed for use on the Space Shuttle mid-deck and Space Lab respectively. These R/F systems have been used for short term storage of such items as food, medicines, experiment supplies, and for plant and biological samples. They are designed to operate at temperatures ranging from about $-22^{\circ} \mathrm{C}$ to $+4^{\circ} \mathrm{C}$, and are similar in size and shape to the small domestic units often used in college dormitories. Both units employ similar technology and have similar designs, with the LSLE units being about twice the storage volume of the OR/F units. Cooling for these units, which use CFC refrigerants, has been provided by conventional Rankine cycle (vapor compression) systems that were extensively modified to meet the Shuttle safety requirements. These units have tended to be noisy and have relatively high vibration. They have an expected life of a few hundred hours and generally need to be reconditioned after each mission.

A Stirling cycle cooled OR/F (SOR/F) system, built by Martin Marietta and Sunpower, illustrated in figure 1 , recently flew successfully as an experiment on STS-60. This unit demonstrated much lower levels of noise and vibration than previous systems, and is expected to have a much longer life and require less maintenance. The EOR/F, an enhanced version of the OR/F with a Rankine cycle cooler employing a linear compressor and HCFC refrigerant, is scheduled to fly on IML-2 in July, 1994. The $\mathrm{EOR} / \mathrm{F}$ is expected to demonstrate improvements similar to the SOR/F. 


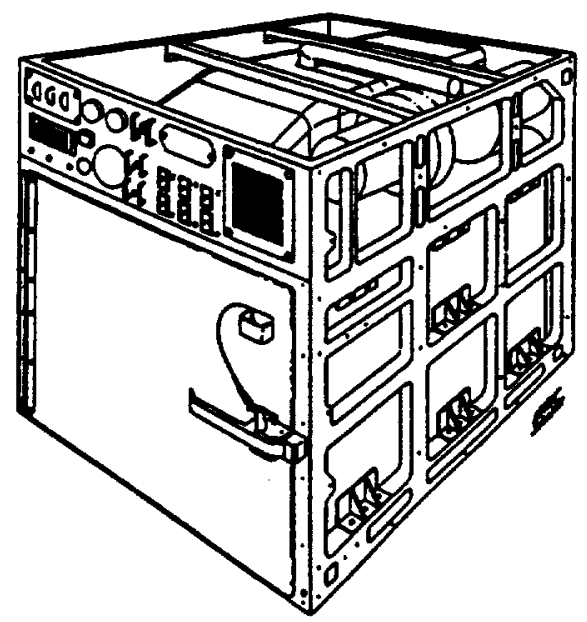

Figure 1. Stining ORF (SORF)

Future manned space missions are anticipated to be longer in duration than current Space Shuttle missions, which are generally limited to 14 days. The International Space Station Alpha (ISSA) will provide the opportunity to extend mission times to months or even years. It is likely that much of the food, medicines, experiment supplies, and experiment samples collected during these missions will be transported and stored as either refrigerated or frozen matter. In order to minimize deterioration over extended storage periods, many of the perishable items must be stored at near liquid nitrogen temperature $\left(-196^{\circ} \mathrm{C}\right)$.

About half of the planned ISSA missions involve life and biomedical sciences experiments, which will be conducted by about 60 diverse groups of researchers and scientists. R/F laboratory equipment, most of which needs to be developed, is enabling to about $75 \%$ of these experiments. In December of 1992 , an R/F Technology Team, consisting of scientists and engineers from NASA Headquarters, Goddard Space Flight Center, Johnson Space Center, Lewis Research Center, and Marshall Space Flight Center, was assembled to qualitatively assess the state of R/F technology. After about six months of investigation, the team found that the technologies needed for future R/F systems do not exist at an adequate state of development to provide the advanced R/F technologies required for future life and biomedical sciences spaceflight experiments. They concluded that a technology development program is needed for future R/F systems. In January of this year, a NASA Headquarters Memorandum of Understanding (MOU), between the Life and Biomedical Sciences and Applications Division (Code UL) and the Spacecraft and Remote Sensing Division (Code CD), was signed. The MOU commissioned Code $C D$ to undertake a technology development project to provide the advanced $R / F$ technologies required for future life and biomedical sciences spaceflight experiments. The MOU assigned the task of implementing the R/F technologies development to the Power Technology Division of Lewis Research Center. This three year project is jointly funded by Codes CD and UL.

\section{OBJECTIVE}

The objective of this project is to develop and demonstrate the key advanced refrigerator/freezer technologies required for future life and biomedical sciences spaceflight experiments. 


\section{TECHNICAL APPROACH AND SCHEDULE}

This project consists of three major activities: 1) determine the R/F system requirements, 2) assess the R/F technologies on a systems basis and determine the best system(s) to meet those requirements, and 3) develop and demonstrate the needed technologies in a brassboard (approaches form and fit, as well as function) R/F system. Item 1 is primarily a NASA "in house" activity to gather the user's requirements, spacecraft interface requirements, and logistical requirements into a single document. Items 2 and 3 , the main technical efforts in this project, will be accomplished by contract. A limited amount of "in house" analysis and technology development may be undertaken to verify and/or enhance the contract effort. As resources allow, consideration may be given to additional contract effort, outside of the main effort, for development of new high-payoff R/F technologies. The expertise within NASA LeRC and the other NASA field centers will be utilized to consult, advise, and assist in the appropriate technical areas as required. To the extent that it is possible, the activities of this project will be coordinated with Space Shuttle and International Space Station Alpha efforts to ensure that this work is complementary to the manned flight program. NASA and other U.S. Government supported efforts outside this project will be followed for synergistic opportunities. The project schedule, including major milestones, is shown in Figure 2. The schedule time is shown in U.S. Government fiscal years, which begin October 1 and end September 30.

Multiple contract awards are possible for the Phase I technology assessment (contract base effort). In the technology assessment, R/F system concepts will be generated that meet the requirements of each R/F classification and their performance will be substantiated through system analysis. This effort will focus on the integration and optimization of the complete R/F systems. A major goal of this activity is to minimize the number of technologies needing development to cover all of the R/F classes, while meeting the system performance requirements. Quality Function Deployment (QFD) or a similar matrix analysis method will be utilized throughout the project, to ensure that all of the requirements are addressed and that all project goals are met. The base effort will include recommendations for the candidate R/F technologies to be developed, and definition of the candidate concepts for the brassboard R/F system to be designed, built and demonstration tested in an optional portion of the contract. Plans for the technology development and brassboard demonstration will also be generated. The results of the Phase I effort will be documented in a final report.

Upon completion of the technology assessment, should multiple contracts exist, there will be a downselection to a single contractor to perform the technology development and brassboard demonstration (optional portion of the contract). In this effort, selected key advanced R/F technologies will be developed. A brassboard R/F system will be designed, fabricated, and tested to demonstrate the pertinent technologies and compliance to the R/F system(s) requirements. Results of Phase II will be documented in a separate final report.

\begin{tabular}{|c|c|c|c|c|}
\hline & \multicolumn{4}{|c|}{$\mathbf{F Y}$} \\
\hline ACTIVITY & 94 & 95 & 96 & 97 \\
\hline $\begin{array}{l}\text { MOU SIGNED } \\
\text { ESTABLISH REOUIREMENTS } \\
\text { ISSUE RFP } \\
\text { AWARD CONTRACTIS) } \\
\text { PHASE I TECHNOLOGY } \\
\text { ASSESSMENT } \\
\text { DOWN-SELECTON } \\
\text { PHUSE II - DEVELOPMENT } \\
\text { DEMONSTRATION } \\
\text { FINUL REPORTS }\end{array}$ & $\Delta$ & ${ }_{\Delta}^{\Delta}$ & & $\Delta$ \\
\hline
\end{tabular}

Figure 2. Advanced R/F Technology Development Project Schedule 


\section{LIFE AND BIOMEDICAL SCIENCES R/F SYSTEMS DESCRIPTION}

Five nominal classes of refrigerator/freezer equipment, have been identified by the researcher and scientist user community as being needed to satisfy the requirements for the future life and biomedical sciences experiments:

$-20^{\circ} \mathrm{C}$ Storage Freezer
$-70^{\circ} \mathrm{C}$ Storage Freezer
$-70^{\circ} \mathrm{C}$ Freeze Dryer
Cryogenic Storage Freezer $\left(\leq-183^{\circ} \mathrm{C}\right)$
Cryogenic Quick/Snap Freezer $\left(\leq-183^{\circ} \mathrm{C}\right)$

The requirements for these R/F systems are somewhat extensive, reflecting the needs of the end users and the interface constraints imposed by implementation of these systems on board the Space Shuttle and International Space Station Alpha. They are based on the requirements established in references 1-3, results of the International Refrigerator/Freezer Workshop conducted in March, 1994 by Johnson Space Center, and subsequent feedback from the users. The requirements currently address little of the logistics associated with specimen handling and transport between the space station and shuttle, and between the shuttle and the laboratory where the samples will be processed. To the extent that it is possible, these logistical requirements will be given consideration as they become better defined. The following are general descriptions of each R/F equipment class and some of their unique functional requirements.

\section{$-20^{\circ} \mathrm{C}$ Storage Freezer}

General Description. The $-20^{\circ} \mathrm{C}$ storage freezer is a low temperature storage facility which maintains the temperature at $-19^{\circ} \mathrm{C}$ or below for life science specimens (feces, blood, urine, sweat, tissue samples,etc.), reagents, chemicals, medical/biological specimens, and perishable supplies. It is anticipated that this equipment would operate continuously throughout a mission.

Functional Requirements. The $-20^{\circ} \mathrm{C}$ storage freezer must maintain storage temperature within $\pm 1^{\circ} \mathrm{C}$ of the set temperature during steady-state operation and during defrost. It must be capable of returning the cold space storage volume to $-19^{\circ} \mathrm{C}$ or below within 45 minutes of an addition of a specimen or specimens of thermal capacity equal to $100 \mathrm{ml}$ of standard biological saline solution at an initial temperature of $37^{\circ} \mathrm{C}$. The freezer must maintain the temperature (both core and surface) of the stored specimens below $-19^{\circ} \mathrm{C}$ during a door open operation and specimen removal or addition. The duration of a door opening is typically 30 to 90 seconds. The average door open operation is about 50 seconds. The system must provide racks and shelves for sample storage, and provide an interface to the data management system for monitoring cold storage volume temperatures. The cold storage volume must be at least $0.3 \mathrm{~m}^{3}$, and the maximum external volume is not to exceed $0.6 \mathrm{~m}^{3}$. Maximum power consumption must be less than 456 Watts. Average power consumption must not exceed 200 Watts. The total weight should not exceed $100 \mathrm{~kg}$.

\section{$-70^{\circ} \mathrm{C}$ Storage Freezer}

General Description. The $-70^{\circ} \mathrm{C}$ storage freezer is a low temperature storage facility which maintains the temperature at $-68^{\circ} \mathrm{C}$ or below during steady-state operation for life science specimens, reagents, chemicals, and perishable supplies. It is anticipated that this equipment would operate continuously throughout a mission. 
Functional Requirements. The $-70^{\circ} \mathrm{C}$ storage freezer must maintain storage temperature within $\pm 1^{\circ} \mathrm{C}$ of the set temperature during steady-state operation and during defrost. It must be capable of returning the cold space storage volume to $-68^{\circ} \mathrm{C}$ or below within 45 minutes of an addition of a specimen or specimens of thermal capacity equal to $100 \mathrm{ml}$ of standard biological saline solution at an initial temperature of $37^{\circ} \mathrm{C}$. The freezer must maintain the temperature (both core and surface) of the stored specimens at $-68^{\circ} \mathrm{C}$ or below during a door open operation and specimen removal or addition. The duration of a door opening shall not exceed 30 seconds. The system must provide racks and shelves for sample storage, and provide an interface to the data management system for monitoring cold storage volume temperatures. The cold storage volume must be at least $0.4 \mathrm{~m}^{3}$, and the maximum external volume is not to exceed $0.9 \mathrm{~m}^{3}$. Maximum power consumption must be less than 700 Watts. The average power consumption must not exceed 200 Watts. The total weight should not exceed $269 \mathrm{~kg}$.

\section{$-70^{\circ} \mathrm{C}$ Freeze Dryer}

General Description. The freeze dryer provides a capability to preserve experiment specimens by sublimating the moisture from frozen specimens in a high vacuum, when the specimen to be freeze dried is at an initial temperature of $-70^{\circ} \mathrm{C}$ or below.

Functional Requirements. The freeze dryer must sublimate frozen specimens at or below a pressure of $10^{-4}$ torr and have an ice removal capacity of 1 liter/day (water equivalent). It must provide for an interface to a data management system for monitoring cold storage volume temperatures and pressure. Interfaces shall also be provided for:

A Gaseous Nitrogen Subsystem

A Vacuum Subsystem

A Waste Gas Management Subsystem

A Reclaimable Water Subsystem

The cold volume requirement is yet to be determined, and the total external volume must not exceed 0.3 $\mathrm{m}^{3}$. Maximum power consumption must be less than $\mathbf{4 0 0}$ Watts. Average power consumption must not exceed 200 Watts. The total weight should not exceed $73 \mathrm{~kg}$.

\section{Cryogenic Storage Freezer}

General Description. The cryogenic storage freezer is used for cryogenically storing specimens or samples at $-183^{\circ} \mathrm{C}$ or below. It is anticipated that this equipment would operate continuously throughout a mission.

Functional Requirements. The cryogenic storage freezer must be capable of maintaining the temperature (both core and surface) of the stored specimens at $-183^{\circ} \mathrm{C}$ or below from the time they are frozen until they are accessed by the ground crew. The system must provide for individual removal of stored samples while maintaining the temperature of the remaining stored samples at $-183^{\circ} \mathrm{C}$ or below. The system must maintain the temperature of the stored samples during the defrost procedure and provide an interface to the data management system for monitoring cold storage volume temperatures. The cold storage volume must be at least $0.02 \mathrm{~m}^{3}$ and the maximum external volume is not to exceed $0.2 \mathrm{~m}^{3}$. Maximum power consumption must be less than 245 Watts. The average power consumption must not exceed 200 Watts. The total weight should not exceed $122.5 \mathrm{~kg}$. 


\section{Cryogenic Quick/Snap Freezer}

General Description. The cryogenic quick/snap freezer is used for "quick freezing" and "snap freezing" of life sciences specimens and protein crystals at $-196^{\circ} \mathrm{C}$.

Functional Requirements. The cryogenic quick/snap freezer must provide a quick freezer capability to reduce the temperature of a $2 \mathrm{ml}$ specimen to $-196^{\circ} \mathrm{C}$ in no more than 10 minutes and provide a snap freezer capability such that vitrification of skeletal muscle is achieved to a depth of $15 \mu \mathrm{m}$ at $-196^{\circ} \mathrm{C}$ or below. Vitrification is defined as no ice crystals larger than 10 Angstroms present. The freezer must accommodate up to twenty (20) $2 \mathrm{ml}$ or ten (10) $5 \mathrm{ml}$ specimen sample wells in the freezer block. Wells for the $5 \mathrm{ml}$ samples should be the same diameter and geometry (tapered) as the $2 \mathrm{ml}$ wells. The freezer must also accommodate crystal growth samples, such that a protein crystal, $0.5 \mathrm{~mm} \times 0.5 \mathrm{~mm} \times 0.5 \mathrm{~mm}$, freezes in not more than one second. The system must accommodate specimen transfer to the cryogenic storage freezer while maintaining temperatures at $-183^{\circ} \mathrm{C}$ or lower and provide an interface to the data management system for monitoring cold storage volume temperatures. It must perform as specified when installed in the Life Sciences Glovebox or the Microgravity Sciences Glovebox. The cold storage volume has yet to be determined and the maximum external volume is not to exceed $0.03 \mathrm{~m}^{3}$. Maximum power consumption must be less than 180 Watts. Average power consumption must not exceed 180 Watts. The total weight should not exceed $29.5 \mathrm{~kg}$.

\section{Requirements Common to All Five R/F Classes}

The following are some of the functional requirements that are common to all five R/F classes.

Cold Space Storage Volume. Temperature variations within the cold storage volume shall be within $\pm 1^{\circ} \mathrm{C}$. The equipment shall be capable of controlling the frost build-up. Defrost shall be accomplished with a minimum of human intervention and in a manner that maintains overall system cooling capabilities.

Door Openings. Door openings shall provide access to the cold volume for sample insertion and removal. The equipment usage profile (number of opening operations with respect to time) is to be determined.

External Environmental Conditions. These equipment are intended for installation in areas that will be occupied by the flight crew and therefore, will be exposed to the conditions encountered in the cabin space. Under normal conditions, the air temperature is expected to range from $18^{\circ} \mathrm{C}$ to $40^{\circ} \mathrm{C}$,. the pressure range is from $70 \mathrm{kPa}$ to $103 \mathrm{kPa}$ (absolute,) and the humidity range is from $1.7^{\circ} \mathrm{C}$ to $40^{\circ} \mathrm{C}$ dewpoint. During launch and landing the temperature can range from $-10^{\circ} \mathrm{C}$ to $66^{\circ} \mathrm{C}$, pressure may range from $55 \mathrm{kPa}$ to $103 \mathrm{kPa}$, and the dewpoint range is expected to be the same as for normal conditions. The R/F equipment, while operating, must be capable of withstanding the random vibration and acoustic environment of the spacecraft during launch and landing with little or no impact on the system life and reliability. The equipment must be capable of operating in a zero-g to one-g environment for all launch and landing orientations.

Heat Rejection. The method of heat rejection must be adaptable to use of either cabin air or water as the coolant. If cabin air is used as the coolant (typical for Space Shuttle,) the external environmental conditions stated above apply. In addition, the maximum air temperature exiting this equipment shall not exceed $49^{\circ} \mathrm{C}$. 
If water is used as the coolant (typical for Space Station Alpha), the following limits apply. The maximum heat rejection rate (per $R / F$ unit) to the water must not exceed 810 Watts. Water inlet temperature is expected to range from $3^{\circ} \mathrm{C}$ to $8^{\circ} \mathrm{C}$. The water flow rate may vary from 98 liters/hr to 113 liters $/ \mathrm{hr}$. Water inlet pressure is expected to range from 413 to $689 \mathrm{kPa}$ (absolute.)

Noise. The noise generated by the R/F system during operation must not exceed NC-40 (with a goal of NC-30) in any octave band between $63 \mathrm{~Hz}$ and $8 \mathrm{~Hz}$, when measured at a distance of 0.62 meters ( 2 feet) from the equipment boundary.

Vibration. Each R/F system must exhibit low vibration generation characteristics during operation and have structural mounting characteristics that are compatible with the spacecraft. The equipment must have no resonant frequencies below $35 \mathrm{~Hz}$ when constrained at the rack interface. Vibration levels generated by the equipment shall not exceed the following limits:
$0.1-10 \mathrm{~Hz}$
$18.0 \mathrm{~N}$
$10-20 \mathrm{~Hz}$
$7.1 \mathrm{~N}$
$20-28 \mathrm{~Hz}$
$1.3 \mathrm{~N}$
$28-80 \mathrm{~Hz}$
$10.0 \mathrm{~N}$

Working Fluid. The working fluid must be non-CFC/HCFC and non-toxic.

Operational Lifetime. This equipment is expected to be in service for 5 years or more of continuous operation. The operational life goal for spaceflight quality R/F equipment is 10 years with corrective and preventive maintenance.

Maintenance. The goal for total scheduled and unscheduled maintenance is 1.2 Maintenance Man Hours per year $(M M H / Y)$ per $R / F$ unit.

Reliability. This equipment must have high reliability, consistent with that of similar commercially available ground-based life science equipment.

Safety. This R/F equipment must comply with flight safety requirements. Shuttle safety requirements (NTSTS 1700.7B) should be used as a guideline.

Structural/Mounting. Potential use of this equipment may require integration into a U.S. Standard Equipment Rack Assembly (Boeing part number 683-50243-2), a Standard Interface Rack (JSC), a Middeck Accommodations Rack (JSC) or a Spacelab Rack (MSFC).

\section{CONCLUDING REMARKS}

The development of the R/F technologies needed to support future life and biomedical sciences spaceflight experiments promises to be both interesting and challenging. The requirements for small overall size, low system weight, and low power consumption imply careful consideration of the factors that contribute to overall heat load and net R/F system efficiency or coefficient of performance (COP). The many complex and potentially conflicting R/F equipment requirements demand that the project be addressed with a systems approach. It is imperative that the system trade-offs and technologies development be guided by QFD or a similar matrix analysis to ensure that all of the requirements are met, to minimize technical risk, and to ensure the maximum impact from the project. 


\section{REFERENCES}

1. Boeing Aerospace Company, "Refrigerator/Freezer Rack Assembly, " Envelope Drawing Number 683-10043, revision C, (March 6, 1991.)

2. Boeing Aerospace Company, "Cold Equipment, Passive Dosimeter, and Mass Measurement Laboratory Support Equipment," Envelope Drawing Number 683-42003, (August 20, 1992.)

3. "Space Station Support Equipment U.S. Users' Requirements Document," (April 15, 1993.) 


\section{REPORT DOCUMENTATION PAGE}

Public reporting burden for this collection of information is estimated to average 1 hour per response, including the time for reviewing instructions. searching existing data sources, gathering and maintaining the data needed, and completing and reviewing the collection of information. Send comments regarding this burden estimale of any other aspect of this gatherion of intomation, including sugestions for reducing this burden, to Washington Headeuarters Services, Directorate tor Iniormation Operations and Repons, 1215 Jetterson Davis Highway, Suite 1204, Arlington, VA 22202-4302, and to the OHice of Managernent and Budget, Paperwork Reduction Project (0704-0188), Washington, DC 20503.

\begin{tabular}{|l|l|l}
\hline 1. AGENCY USE ONLY (Leave blank) & $\begin{array}{c}\text { 2. REPORT DATE } \\
\text { March } 1995\end{array}$ & $\begin{array}{r}\text { 3. REPORT TYPE AND DATES COVERED } \\
\text { Technical Memorandum }\end{array}$ \\
\hline
\end{tabular}

\section{TITLE AND SUBTTLE}

NASA Advanced Refrigerator/Freezer Technology Development

Project Overview

6. AUTHOR(S)

\section{J.E. Cairelli}

7. PERFORMING ORGANIZATION NAME(S) AND ADDRESS(ES)

National Aeronautics and Space Administration

Lewis Research Center

Cleveland, Ohio 44135-3191

9. SPONSORING/MONITORING AGENCY NAME(S) AND ADDRESS(ES)

National Aeronautics and Space Administration

Washington, D.C. 20546-0001
5. FUNDING NUMBERS

WU-233-03-0A

B. PERFORMING ORGANIZATION REPORT NUMBER

E-9204

10. SPONSORING/MONITORING AGENCY REPORT NUMBER

NASA TM-106309

11. SUPPLEMENTARY NOTES

Responsible person, J.E. Cairelli, organization code 5460, (216) 433-6142.

12a. DISTRIBUTIONAVAILABILTYY STATEMENT

12b. DISTRIBUTION CODE

Unclassified - Unlimited

Subject Category 51

13. ABSTRACT (Maximum 200 words)

NASA Lewis Research Center (LeRC) has recently initiated a three-year project to develop the advanced refrigerator/ freezer (R/F) technologies needed to support future life and biomedical sciences space experiments. Refrigerator/freezer laboratory equipment, most of which needs to be developed, is enabling to about $75 \%$ of the planned space station life and biomedical sciences experiments. These experiments will require five different classes of equipment; three storage freezers operating at $-20^{\circ} \mathrm{C},-70^{\circ} \mathrm{C}$ and $\leq 183^{\circ} \mathrm{C}$, a $-70^{\circ} \mathrm{C}$ freeze-dryer, and a cryogenic $\left(\leq 183^{\circ} \mathrm{C}\right)$ quick/snap freezer. This project is in response to a survey of cooling system technologies, performed by a team of NASA scientists and engineers. The team found that the technologies, required for future R/F systems to support life and biomedical sciences spaceflight experiments, do not exist at an adequate state of development and concluded that a program to develop the advanced R/F technologies is needed. Limitations on spaceflight system size, mass, and power consumption present a significant challenge in developing these systems. This paper presents some background and a description of the Advanced R/F Technology Development Project, project approach and schedule, general description of the R/F systems, and a review of the major $R / F$ equipment requirements.

14. SUBJECT TERMS

Freezers; Requirements; Cryogenic; Life sciences; Space Station; Laboratory equipment

17. SECURTYY CLASSIFICATION OF REPORT Unclassified

\section{SECURTYY CLASSIFICATION OF THIS PAGE}

Unclassified
19. SECURITY CLASSIFICATION OF ABSTRACT

Unclassified 
